\title{
ANALISIS KESULITAN BELAJAR SISWA PADA MATERI OPERASI ALJABAR BAGI SISWA KELAS VII SMP NEGERI 3 SALATIGA
}

\author{
Asri Dwi Kusumawati', Sutriyono²
}

1,2Pendidikan Matematika,Universitas Kristen Satya Wacana, 202014081@student.uksw.edu

\begin{tabular}{l} 
INFO ARTIKEL \\
\hline Riwayat Artikel: \\
Diterima: 02-03-2018 \\
Disetujui: 18-03-2018 \\
\hline
\end{tabular}

Kata Kunci:

Kesulitan Belajar

Operasi Aljabar

\begin{abstract}
ABSTRAK
Abstrak: Penelitian ini bertujuan untuk mengetahui kesulitan-kesulitan yang dialami siswa dalam menyelesaikan persoalan aljabar yang berkaitan dengan konsep dan prinsip, serta faktor-faktor yang menyebabkan kesulitan belajar siswa kelas VII SMP Negeri 3 Salatiga dalam mempelajari aljabar. Metode penelitian adalah kualitatif deskriptif dengan menganalisis kesulitan-kesulitan siswa dari instrumen yang diberikan. Sampel yang diambil adalah siswa kelas VII SMP Negeri 3 Salatiga dengan jumlah subjek yaitu 5 siswa. Hasil penelitian ini menunjukkan bahwa siswa mengalami kesulitan dalam menyelesaikan persoalan aljabar yang berkaitan dengan persentase penguasaan konsep $58 \%$ dan persentase penguasaan prinsip 53\% yang termasuk pada kategori sedang.
\end{abstract}

\begin{abstract}
This study aims to determine the difficulties experienced by students in solving algebraic problems related to the concepts and principles, as well as the factors that cause difficulties in learning grade VII SMP Negeri 3 Salatiga in learning algebra. The research method is qualitative descriptive by analyzing students' difficulties from the given instrument. Samples taken are students of class VII SMP Negeri 3 Salatiga with the number of subjects ie 5 students. The results of this study indicate that students have difficulty in solving algebra problems related to the percentage of mastering the concept of $58 \%$ and the percentage mastery of 53\% which is included in the medium category.
\end{abstract}

\section{A. LATAR BELAKANG}

Sebagian orang pernah menggunakan konsep aljabar dalam permasalahan sehari-hari, baik yang disadari maupun tidak disadari khususnya bagi mereka yang pernah menempuh jenjang pendidikan. Pengenalan konsep aljabar perlu diberikan kepada siswa, karena konsep tersebut akan berguna diberbagai bidang matematika yang akan siswa pelajari. Konsep aljabar tersebut dapat diberikan dan ditanamkan secara efektif dengan mengajarkan aljabar di sekolah.

Pemberian materi aljabar mulai diperkenalkan kepada siswa ditingkat Sekolah Menengah Pertama (SMP). Pembelajaran aljabar bertujuan agar siswa mampu untuk berpikir logis, analitis, sistematis, kritis, kreatif, dan kerjasama. Adapun tujuan pembelajaran matematika di SMP salah satunya adalah pemahaman konsep (Depdiknas: 2006). Karena aljabar merupakan salah satu bagian dari matematika maka pemahaman konsep aljabar merupakan salah satu tujuan yang akan dicapai dalam pembelajaran matematika untuk SMP dan sederajat.

Gagne (Erman, 2003: 33) menyatakan dalam belajar matematika ada dua objek yang dapat diperoleh siswa, yaitu objek langsung dan objek tak langsung. Objek langsung terdiri dari fakta, konsep, skill, dan prinsip. Begle dalam Herman Hudojo (2005: 36) menyatakan bahwa sasaran atau objek penelaahan matematika adalah fakta, konsep, operasi, dan prinsip. Oleh karena itu, setelah siswa belajar mengenai aljabar, diharapkan siswa juga dapat memperoleh keempat hal tersebut yang berkaitan dengan materi aljabar.

Materi Aljabar membahas mengenai pengertian variabel, konstanta, koefisien dan suku-suku yang sejenis dan tidak sejenis. Siswa juga akan mempelajari mengenai operasi hitung pada bentuk aljabar yang menggunakan prinsip-prinsip operasi hitung pada bilangan bulat. Hal ini menjelaskan bahwa setiap materi pada pembelajaran matematika tidak terlepas dengan fakta, konsep dan prinsip.

Beberapa siswa mengalami kesulitan dalam mengikuti pembelajaran matematika di kelas. Kesulitan belajar matematika yang dialami siswa berarti juga kesulitan belajar bagian-bagian matematika. Kesulitan tersebut dapat hanya satu bagian saja, dapat juga lebih dari satu bagian matematika yang dipelajari. Ditinjau dari keragaman materi pelajaran matematika, bahwa satu bahasan berkaitan dengan satu atau lebih bahasan, maka kesulitan siswa pada suatu bahasan akan berdampak kesulitan satu atau lebih bahasan yang lain. Salah satu kesulitan siswa mempelajari satu bagian matematika dapat berdampak pada kesulitan siswa dalam mempelajari bagian matematika yang lain. 
Dari hasil wawancara yang dilakukan dengan guru matematika di SMP Negeri 3 Salatiga, guru menyatakan bahwa siswa kelas VII masih sering melakukan kesalahan saat mengerjakan persoalan yang terkait dengan aljabar. Sesuai dengan pernyataan Soedjadi (1996: 27) yang mengatakan bahwa kesulitan yang dialami siswa akan memungkinkan terjadi kesalahan sewaktu menjawab soal tes. Sebagaimana yang sudah dijelaskan oleh Soedjadi, kesalahan yang dilakukan siswa dalam menjawab persoalan aljabar merupakan bukti adanya kesulitan yang dialami oleh siswa pada materi tersebut. Hubungan antara kesalahan dan kesulitan dapat diperhatikan pada kalimat "jika seorang siswa mengalami kesulitan maka ia akan membuat kesalahan" (Depdikbud: 1982). Hal tersebut menegaskan bahwa kesulitan merupakan penyebab terjadinya kesalahan. Dengan demikian pernyataan guru matematika SMP Negeri 3 Salatiga yang menyatakan bahwa siswa-siswanya masih banyak melakukan kesalahan ketika mengerjakan persoalan aljabar, maka dapat dikatakan bahwa siswa-siswa tersebut mengalami kesulitan dalam mempelajari aljabar.

Hal ini sesuai dengan penelitian yang dilakukan Fajar Hidayati (2010) yang menghasilkan (1) kesulitankesulitan yang dialami siswa kelas VII dalam menyelesaikan persoalan aljabar yang berkaitan dengan konsep dan prinsip adalah (a) di dalam penguasaan konsep, dimana kesulitan tersebut berada dikategori tinggi yaitu $72 \%$; (b) kesalahan yang paling banyak dilakukan siswa dalam penguasaan konsep adalah ketika siswa harus menyajikan himpunan dengan diagram Venn; (c) di dalam penguasaan prinsip, siswa masih mengalami kesulitan dalam mengapreasiasikan peran prinsipprinsip dalam matematika, yang berada pada kategori tinggi yaitu 74\%; (2) faktor-faktor yang menyebabkan kesulitan belajar siswa SMP dalam mempelajari aljabar berasal dari faktor ekstern, yaitu penggunaan alat peraga oleh guru dengan kategori cukup yaitu (49\%).

Oleh karena itu, perlu adanya upaya untuk mengatasi munculnya kesulitan tersebut, beberapa usaha telah dilakukan oleh guru kelas VII pada saat pembelajaran aljabar. Guru memberikan penjelasan kembali kepada siswa tersebut hingga mereka menyatakan bahwa dirinya telah mengerti. Guru juga menanamkan pemahaman konsep melalui model pembelajaran yang digunakan. Dari berbagai usaha yang telah dilakukan oleh guru, ternyata masih terjadi kesulitan belajar yang dihadapi oleh siswa.

Cooney,at all (1975: 204) menyatakan bahwa kesulitan siswa-siswa dalam belajar matematika agar difokuskan pada dua jenis pengetahuan matematika yang penting yaitu pengetahuan konsep-konsep dan pengetahuan prinsip-prinsip. Dengan demikian untuk mengetahui kesulitan belajar siswa dalam mempelajari aljabar dapat ditinjau dari pengetahuan siswa tentang konsep-konsep dan prinsip-prinsip dalam aljabar. Seperti bidang matematika lainnya, aljabar terdiri dari beberapa konsep dan prinsip dimana sebuah konsep aljabar diperlukan sebagai dasar untuk konsep pembelajaran aljabar berikutnya dan penggunaan prinsip yang saling berkaitan akan menjadi modal bagi para siswa untuk dapat menyelesaikan persoalan aljabar dengan baik dan benar.

Pentingnya pemahaman konsep aljabar bagi siswa dan masih banyaknya kesulitan yang dihadapi oleh para siswa maka dirasa perlu untuk dilakukan suatu analisis tentang kesulitan belajar siswa dalam mempelajari aljabar. Hal itu perlu dilakukan agar guru dapat mengetahui letak kesulitan siswa dalam penguasaan konsep dan prinsip dalam aljabar sehingga guru dapat meminimalisir kesalahan-kesalahan siswa dalam mengerjakan persoalan aljabar. Selain itu guru juga dapat mengetahui faktor-faktor yang menyebabkan siswa mengalami kesulitan dalam mempelajari aljabar. Berdasarkan uraian tersebut peneliti tertarik untuk menganalisis kesulitan belajar siswa kelas VII SMP Negeri 3 Salatiga dalam mempelajari aljabar.

\section{B. METODE PENELITIAN}

Jenis penelitian yang digunakan dalam penelitian ini adalah pendekatan kualitatif dan kuantitatif. Penelitian ini dilakukan di SMP Negeri 3 Salatiga dengan pengambilan subjek berdasarkan purposive sampling sebanyak 5 siswa dari kelas VII A. Pengambilan data dilakukan pada bulan Oktober-November. Metode pengumpulan data dalam penelitian ini dengan menggunakan tes tertulis, wawancara dan angket. Instrumen yang digunakan dalam penelitian ini berupa tes uraian yang berisi tentang soalsoal yang berkaitan dengan materi aljabar. Tes yang dilakukan dengan $1 \mathrm{x}$ pertemuan ( 2 jam pelajaran) pada tanggal 21 November 2017. Instrumen wawancara dalam penelitian ini menggunakan pedoman wawancara semi terstruktur.

\section{HASIL DAN PEMBAHASAN}

Berdasarkan penelitian yang dilakukan menghasilkan analisis hasil pekerjaan siswa sebagai berikut:

\section{Analisis Data Hasil Pekerjaan Siswa \\ TABEL 1}

RANGKUMAN HASIL PEKERJAAN SISWA DALAM PENGUASAAN KONSEP DAN PRINSIP

\begin{tabular}{|c|c|c|c|c|}
\hline $\begin{array}{c}\text { Pengua- } \\
\text { Saan }\end{array}$ & Indikator & $\begin{array}{c}\text { Indikator Soal/ } \\
\text { Pengalaman } \\
\text { Belajar }\end{array}$ & $\sum X$ & $\Sigma \sqrt{ }$ \\
\hline \multirow{2}{*}{ Konsep } & \multirow[t]{2}{*}{$\begin{array}{l}\text { 1. Menandai, } \\
\text { mengungkap } \\
\text { kan dengan } \\
\text { kata-kata dan } \\
\text { mengidentifikasi } \\
\text { kan konsep }\end{array}$} & $\begin{array}{l}\text { Siswa dapat } \\
\text { menentukan } \\
\text { variabel dari } \\
\text { suatu bentuk } \\
\text { aljabar }\end{array}$ & 0 & 30 \\
\hline & & $\begin{array}{l}\text { Siswa dapat } \\
\text { menentukan } \\
\text { koefisien dari } \\
\text { suatu bentuk } \\
\text { aljabar }\end{array}$ & 21 & 9 \\
\hline
\end{tabular}




\begin{tabular}{|c|c|c|c|c|}
\hline & & $\begin{array}{lr}\text { Siswa dapat } \\
\text { menentukan } \\
\text { konstanta dari } \\
\text { suatu bentuk } \\
\text { aljabar. }\end{array}$ & 4 & 26 \\
\hline & \multirow{2}{*}{$\begin{array}{l}2 . \\
\text { Mengidentifikasi } \\
\text { contoh dan } \\
\text { bukan contoh } \\
\text { dari konsep }\end{array}$} & $\begin{array}{l}\text { Siswa dapat } \\
\text { menentukan } \\
\begin{array}{l}\text { suku-suku yang } \\
\text { sejenis }\end{array}\end{array}$ & 17 & 13 \\
\hline & & $\begin{array}{l}\text { Siswa dapat } \\
\text { menentukan } \\
\text { suku-suku yang } \\
\text { tidak sejenis }\end{array}$ & 18 & 12 \\
\hline \multirow{5}{*}{ Prinsip } & \multirow[t]{2}{*}{$\begin{array}{l}\text { 1. Mengenali } \\
\text { kapan suatu } \\
\text { prinsip } \\
\text { diperlukan }\end{array}$} & $\begin{array}{l}\text { Siswa dapat } \\
\text { menyederhanakan } \\
\text { bentuk aljabar } \\
\text { dengan } \\
\text { mengelompokkan } \\
\text { suku-suku yang } \\
\text { sejenis }\end{array}$ & 6 & 24 \\
\hline & & $\begin{array}{l}\text { Siswa dapat } \\
\text { menyelesaikan } \\
\text { operasi hitung } \\
\text { penjumlahan dan } \\
\text { pengurangan } \\
\text { bentuk aljabar }\end{array}$ & 26 & 4 \\
\hline & \multirow[t]{3}{*}{$\begin{array}{l}\text { 2. Menggunakan } \\
\text { prinsip operasi } \\
\text { hitung secara } \\
\text { benar }\end{array}$} & $\begin{array}{l}\text { Siswa dapat } \\
\text { menyelesaikan } \\
\text { perkalian bentuk } \\
\text { aljabar dengan } \\
\text { sifat distributif } \\
\text { perkalian } \\
\text { terhadap } \\
\text { penjumlahan dan } \\
\text { sifat distributif } \\
\text { perkalian } \\
\text { terhadap } \\
\text { pengurangan }\end{array}$ & 5 & 25 \\
\hline & & $\begin{array}{l}\text { Menyederhanakan } \\
\text { hasil operasi } \\
\text { pecahan aljabar }\end{array}$ & 23 & 7 \\
\hline & & $\begin{array}{lr}\text { Siswa dapat } \\
\text { membagi suatu } \\
\text { pecahan dengan } \\
\text { pecahan dengan } \\
\text { cara mengalikan } \\
\text { terhadap } \\
\text { kebalikan pecahan } \\
\text { tersebut. }\end{array}$ & 12 & 18 \\
\hline
\end{tabular}

Dari hasil persentase tingkat kesulitan siswa dalam penguasaan konsep dan prinsip yang termasuk pada kriteria sedang dan rendah terlihat jelas pada Gambar 1.

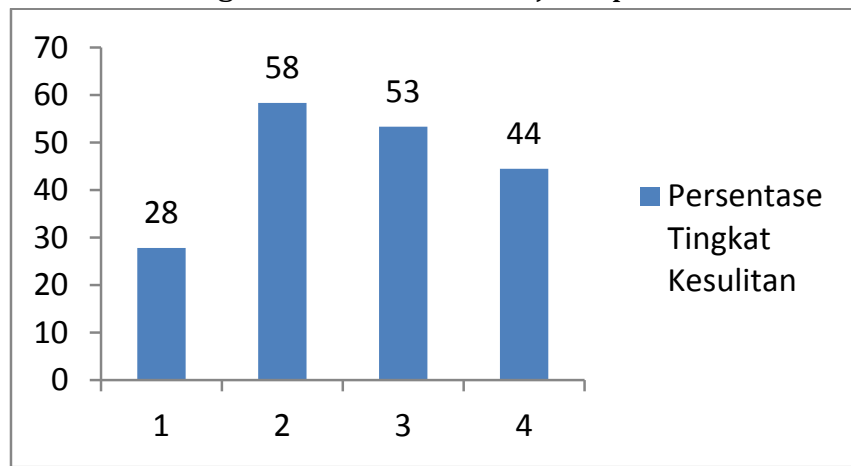

Gambar 1. Persentase Tingkat Kesulitan
TABEL 2

PERSENTASE TINGKAT KESULITAN SISWA

DALAMPENGUASAAN KONSEP DAN PRINSIP

\begin{tabular}{|c|c|c|c|}
\hline $\begin{array}{l}\text { Pengua- } \\
\text { saan }\end{array}$ & Indikator & $\begin{array}{c}\text { Persentase } \\
\text { Tingkat } \\
\text { Kesulitan } \\
\text { Siswa }\end{array}$ & Kriteria \\
\hline \multirow[t]{2}{*}{ Konsep } & $\begin{array}{l}\text { 1.Menandai, } \\
\text { mengungkapkan } \\
\text { dengan kata- } \\
\text { kata dan } \\
\text { mengidentifikasi } \\
\text { kan konsep }\end{array}$ & 28 & Rendah \\
\hline & $\begin{array}{l}2 . \\
\text { Mengidentifikasi } \\
\text { contoh dan } \\
\text { bukan contoh } \\
\text { dari konsep } \\
\end{array}$ & 58 & Sedang \\
\hline \multirow{2}{*}{ Prinsip } & $\begin{array}{lr}1 . & \text { Mengenali } \\
\text { kapan } & \text { suatu } \\
\text { prinsip } & \\
\text { diperlukan } & \\
\end{array}$ & 53 & Sedang \\
\hline & $\begin{array}{l}\text { 2. Menggunakan } \\
\text { prinsip operasi } \\
\text { hitung secara } \\
\text { benar }\end{array}$ & 44 & Sedang \\
\hline
\end{tabular}

Tabel 3

Taraf atau Tingkat Kesulitan

\begin{tabular}{|c|c|}
\hline $\begin{array}{c}\text { Taraf/Tingkat } \\
\text { Kesulitan }(\%)\end{array}$ & Kriteria \\
\hline $80-100$ & Sangat Tinggi \\
\hline $66-79$ & Tinggi \\
\hline $40-65$ & Sedang \\
\hline $0-39$ & Rendah \\
\hline
\end{tabular}

Sumber : (Suharsimi Arikunto, 1998: 246)

Kesalahan-kesalahan yang dilakukan siswa terkait dengan Penguasaan Konsep dan Prinsip aljabar beradasarkan hasil tes dan wawancara, yaitu:

1. Kesalahan siswa dalam menandai, mengungkapkan dengan kata-kata dan mengidentifikasikan konsep.

Kesalahan siswa dalam menandai, mengungkapkan dengan kata-kata dan mengidentifikasikan konsep terjadi jika siswa tidak dapat menentukan kofisien dan konstanta dari suatu bentuk aljabar.

Berikut contoh hasil pekerjaan siswa yang disertai dengan hasil wawancara siswa yang melakukan kesalahan:

a. Siswa tidak dapat menentukan koefisien dari suatu variabel.

Pada soal nomor $1 \mathrm{~b}$ siswa diminta untuk menentukan variabel $\mathrm{x}$ dari bentuk aljabar $10 y-$ $4 x+4 y+6 x$ 


\begin{tabular}{|l|l|}
\hline Jawaban siswa G & \multicolumn{1}{|c|}{\begin{tabular}{|} 
Jawaban yang di \\
harapkan
\end{tabular}} \\
\hline b. 4 dan 6 & $\begin{array}{l}\text { 1b. Koefisien dari } \\
\text { variabel x adalah -4 } \\
\text { dan } 6\end{array}$ \\
\hline
\end{tabular}

b. Siswa tidak dapat menentukan konstanta dari suatu bentuk aljabar

Pada soal nomor 1c siswa diminta untuk menentukan konstanta dari bentuk aljabar $10 y-$ $4 x+4 y+6 x$

\begin{tabular}{|c|l|}
\hline Jawaban siswa R & \multicolumn{1}{|c|}{$\begin{array}{c}\text { Jawaban yang di } \\
\text { harapkan }\end{array}$} \\
\hline c. $u$ dan $y \quad$ & $\begin{array}{l}\text { 1c. Konstanta dari } \\
\text { bentuk aljabar 10y- } \\
4 x+4 y+6 x \text { adalah 0 } \\
\text { atau tidak ada. }\end{array}$ \\
\hline
\end{tabular}

Berdasarkan hasil wawancara oleh kedua siswa $\mathrm{G}$ dan $R$, dapat disimpulkan bahwa siswa G tidak mengetahui definisi dari koefisien atau dapat dikatakan siswa tidak dapat mengungkapkan dengan kata-kata definisi dari koefisien. Serta siswa $\mathrm{R}$ sebenarnya mengetahui definisi dari konstanta namun tidak dapat mengungkapkan dengan kata-kata definisi dari suatu konstanta sehingga dapat dikatakan bahwa siswa tidak dapat mengungkapkan dengan kata-kata definisi dari konstanta. Oleh karena itu, dapat disimpulkan bahwa kedua siswa tersebut tidak dapat mengungkapkan definisi dengan kata-kata.

2. Kesalahan siswa dalam mengidentifikasi contoh dan bukan contoh dari konsep.

Kesalahan dalam indikator penguasaan konsep di atas terjadi jika siswa tidak dapat menentukan sukusuku yang sejenis dan tak sejenis dari suatu bentuk aljabar.

Berikut contoh hasil pekerjaan siswa yang disertai dengan hasil wawancara siswa yang melakukan kesalahan:

a. Siswa tidak dapat menentukan suku-suku yang sejenis dari suatu bentuk aljabar.

Pada soal nomor 1d siswa diminta untuk menentukan suku yang sejenis dari bentuk aljabar $10 y-4 x+4 y+6 x$

\begin{tabular}{|c|l|}
\hline Jawaban siswa J & \multicolumn{1}{|c|}{$\begin{array}{c}\text { Jawaban yang } \\
\text { diharapkan }\end{array}$} \\
\hline d. $10 y+4 y-4 u+6 u$ & $\begin{array}{l}1 \text { d. Suku yang } \\
\text { sejenis adalah } \\
10 y \text { dan } 4 y \text {, dan }- \\
4 x \text { dan } 6 x\end{array}$ \\
\hline
\end{tabular}

Dari wawancara di atas terlihat bahwa siswa belum dapat menuliskan suku-suku yang sejenis secara benar dan tepat. Sehingga dapat dikatakan siswa belum dapat menentukan contoh dan bukan contoh dari konsep suku-suku yang sejenis.

b. Siswa tidak dapat menentukan suku-suku yang tak sejenis dari suatu bentuk aljabar.

Pada soal nomor 1d siswa diminta untuk menentukan suku yang tak sejenis dari bentuk aljabar $10 y-4 x+4 y+6 x$

\begin{tabular}{|c|c|}
\hline Jawaban siswa A & $\begin{array}{l}\text { Jawaban yang } \\
\text { diharapkan }\end{array}$ \\
\hline 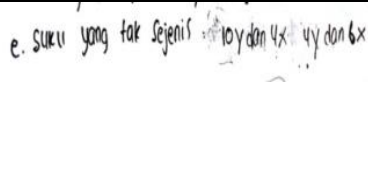 & $\begin{array}{l}\text { 1e. Suku yang tak } \\
\text { sejenis } \\
10 y \text { dan - } \\
4 x \text {, dan } 4 y \text { dan } 6 x\end{array}$ \\
\hline
\end{tabular}

Dari wawancara di atas terlihat bahwa siswa belum dapat menuliskan suku-suku yang tak sejenis secara benar dan tepat. Sehingga dapat dikatakan siswa belum dapat menentukan contoh dan bukan contoh dari konsep suku-suku yang tak sejenis.

3. Kesalahan siswa dalam mengenali kapan suatu prinsip diperlukan.

Kesalahan dalam indikator penguasaan prinsip di atas terjadi jika siswa tidak dapat menyederhanakan bentuk aljabar dengan mengelompokkan suku-suku yang sejenis, dan siswa tidak dapat menggunakan operasi hitung penjumlahan dan pengurangan.

Berikut contoh hasil pekerjaan siswa yang disertai dengan hasil wawancara siswa yang melakukan kesalahan:

a. Siswa tidak dapat menyederhanakan bentuk aljabar dengan mengelompokkan suku-suku yang sejenis.

Pada soal nomor 2a siswa diminta untuk mengubah bentuk aljabar $2 a+3 b-a+5 b$ ke dalam bentuk aljabar yang paling sederhana, dengan mnyertakan langkah-langkah pengerjaannya.

\begin{tabular}{|c|c|}
\hline Jawaban siswa R & $\begin{array}{c}\text { Jawaban yang } \\
\text { diharapkan }\end{array}$ \\
\hline $2 a \cdot 2 a+3 b-a+5 b$ & $2 a \cdot 2 a+3 b-a+5 b$ \\
$2 a-a+3 b+5 b$ & $=2 a-a+3 b$ \\
$3 a+8 b$ & $+5 b$ \\
& $=a+8 b$ \\
\hline
\end{tabular}

\begin{tabular}{|c|c|}
\hline Jawaban siswa M & $\begin{array}{c}\text { Jawaban yang } \\
\text { diharapkan }\end{array}$ \\
\hline $2 \cdot a \cdot 2 a+3 b-a+5 b$ & $2 a \cdot 2 a+3 b-a+5 b$ \\
$2 a^{2}+(3+5) b$ & $=2 a-a+3 b$ \\
$2 a^{2}+8 b$ & $+5 b$ \\
& $=a+8 b$ \\
\hline
\end{tabular}

Berdasarkan hasil pekerjaan siswa yang kemudian dilakukan wawancara, diperoleh informasi bahwa 
siswa $R$ tidak dapat menyelesaikan penyederhanaan bentuk aljabar tersebut dengan benar, siswa salah dalam operasi pengurangan bentuk aljabar dan siswa $M$ tidak dapat menyelesaikan penyederhanaan bentuk aljabar tersebut dengan benar, siswa salah dalam konsep pengurangan bentuk aljabar. Oleh karena itu, dapat dikatakan bahwa kedua siswa tersebut masih mengalami kesulitan dalam menyederhanakan bentuk aljabar dengan mengelompokkan suku-suku yang sejenis. Sehingga dapat dikatakan bahwa kedua siswa tersebut mengalami kesulitan dalam hal mengenali kapan suatu prinsip diperlukan.

b. Siswa tidak dapat menyelesaikan operasi hitung penjumlahan dan pengurangan bentuk aljabar.

Pada soal nomor $2 \mathrm{~b}$ siswa diminta untuk menyelesaikan operasi hitung penjumlahan dan pengurangan bentuk aljabar $(12 x+5 y)-$ $(-2 x-3 y)$ ke dalam bentuk aljabar yang paling sederhana, dengan menyertakan langkah-langkah pengerjaannya.

\begin{tabular}{|c|c|}
\hline Jawaban siswa J & $\begin{array}{c}\text { Jawaban yang } \\
\text { diharapkan }\end{array}$ \\
\hline b. $(12 u+5 y+5)-(-2 u-3 y)$ & $\begin{array}{l}\text { b. }(12 x+5 y)- \\
(-2 x-3 y) \\
-24 u^{2}+36 u y-10 y u-15 y^{2} \\
-24 u^{2}+36 u y+10 y u-15 y^{2}\end{array}$ \\
& $+2 x+3 y$ \\
& $=12 x+2 x$ \\
& $+5 y+3 y$ \\
& $=14 x+8 y$ \\
\hline
\end{tabular}

Dari jawaban dan hasil wawancara dengan siswa J, maka dapat dikatakan bahwa siswa J masih mengalami kesulitan dalam menyelesaikan operasi penjumlahan dan pengurangan bentuk aljabar. Sehingga dapat dikatakan bahwa siswa mengalami kesulitan dalam hal mengenali kapan suatu prinsip diperlukan.

4. Kesalahan siswa dalam menggunakan prinsip secara benar.

Kesalahan dalam indikator penguasaan prinsip di atas terjadi jika siswa tidak dapat menyelesaikan perkalian dengan menggunakan sifat distributif, serta siswa tidak dapat menyederhanakan hasil operasi dan membagi suatu pecahan.

Berikut contoh hasil pekerjaan siswa yang disertai dengan hasil wawancara siswa yang melakukan kesalahan:

a. Siswa tidak dapat menyelesaikan perkalian bentuk aljabar dengan sifat distributif perkalian terhadap penjumlahan dan sifat distributif perkalian terhadap pengurangan.

Pada soal nomor 2c siswa diminta untuk mengubah bentuk aljabar $3(2 p+3 q)+2(p-2 q)$ ke dalam bentuk aljabatr yang paling sederhana, dengan menyertakan langkah-langkahnya. Dalam langkah-langkah tersebut siswa akan menggunakan operasi hitung bentuk perkalian dengan sifat distibutif perkalian, penjumlahan dan pengurangan.

\begin{tabular}{|c|c|}
\hline Jawaban siswa A & $\begin{array}{c}\text { Jawaban yang } \\
\text { diharapkan }\end{array}$ \\
\hline c. $3(2 p+3 q)+2(p-2 q)$ & 2 c. $3(2 p+3 q)+$ \\
$\Leftrightarrow(6 p+9 q)+(2 p-4 q)$ & $2(p-2 q)$ \\
& $=6 p+9 q$ \\
& $+2 p-4 q$ \\
$\Leftrightarrow(6 p-2 p)+(-4 q-9 q)$ & $=6 p+2 p$ \\
& $+9 q-4 q$ \\
& $=2 p+5 q$ \\
&
\end{tabular}

Dari jawaban dan hasil wawancara dengan siswa A, maka dapat dikatakan bahwa siswa A masih mengalami kesulitan dalam menggunakan sifat distributif perkalian. Sehingga dapat dikatakan bahwa siswa mengalami kesulitan dalam menggunakan prinsip secara benar.

b. Siswa tidak dapat menyederhanakan hasil operasi pecahan aljabar.

Pada soal nomor 2d siswa diminta untuk mengubah bentuk aljabar $\frac{2 k}{3}+\frac{1+3 k}{2}$ ke dalam bentuk aljabar yang paling sederhana, dengan menyertakan langkah-langkahnya.

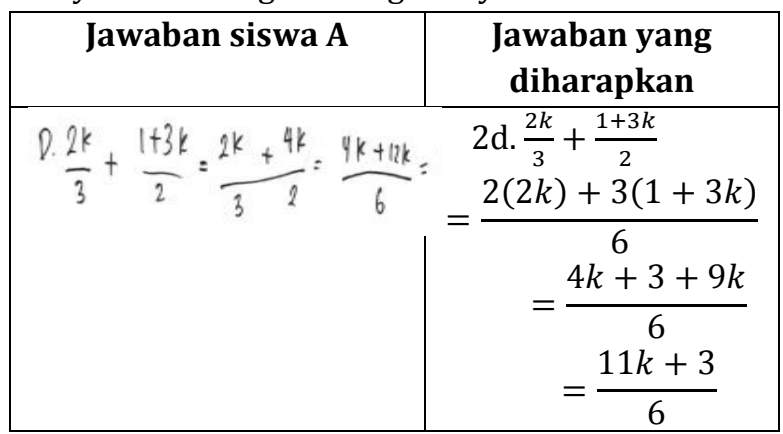

Dari jawaban dan hasil wawancara dengan siswa A, terlihat bahwa siswa A mengalami kesulitan dalam melakukan operasi penjumlahan pecahan pada bentuk aljabar. Sehingga dapat dikatakan bahwa siswa masih mengalami kesulitan dalam menggunakan prinsip operasi hitung secara benar.

c. Siswa tidak dapat membagi suatu pecahan dengan cara mengalikan tehadap kebalikan pecahan tersebut.

Pada soal nomor 2e, siswa diminta untuk mengubah bentuk aljabar $\frac{2 p}{6} \div \frac{p q}{12}$ ke dalam bentuk aljabar yang paling sederhana, dengan menyertakan langkah-langkahnya. Karena soal tersebut merupakan pembagian pecahan dengan pecahan, maka langkah awal untuk mengerjakan soal tersebut adalah mengalikan dengan kebalikan pecahan tersebut. 


\begin{tabular}{|c|c|}
\hline Jawaban siswa $R$ & Jawaban yang \\
\hline $\begin{aligned} e \frac{2 P}{6}: \frac{P Q}{12} & =\left(3 \frac{2}{2} \frac{2 P}{2}\right):\left(\frac{6}{2} \frac{P Q}{Q^{2}}\right) \\
& =12(2 P):(\alpha P Q) \\
& =2 A P: 6 P Q\end{aligned}$ & $\begin{aligned} 2 e \cdot \frac{2 p}{6} & \div \frac{p q}{12} \\
& =\frac{2 p}{6} \times \frac{12}{p q} \\
& =\frac{2 p \cdot 12}{6 . p q} \\
& =\frac{2 p .12}{2 p .3 q} \\
& =\frac{2 p .3 .4}{2 p .3 q} \\
& =\frac{4}{q}\end{aligned}$ \\
\hline
\end{tabular}

Dari jawaban dan hasil wawancara dengan siswa $\mathrm{R}$, maka dapat dikatakan bahwa siswa $\mathrm{R}$ masih mengalami kesulitan dalam membagi suatu pecahan dengan pecahan dengan cara mengalikan terhadap kebalikan pecahan tersebut. Sehingga dapat dikatakan bahwa siswa masih mengalami kesulitan dalam menggunakan prinsip operasi hitung secara benar.

Data dari angket yang digunakan untuk mengungkapkan faktor-faktor yang menyebabkan kesulitan belajar siswa kelas VII SMP Negeri 3 Salatiga dalam mempelajari aljabar. Setelah data dihitung dengan persentase kemudian diberi predikat untuk masingmasing indikator. Berikut hasil analisis dari masingmasing faktor yang disajikan dalam tabel 4 .

TABEL 4

PERSENTASE FAKTOR-FAKTOR PENYEBAB KESULITAN BELAJAR SISWA

\begin{tabular}{|c|c|c|c|c|}
\hline Faktor & Aspek & Indikator & $\%$ & Kriteria \\
\hline $\begin{array}{l}\text { Faktor } \\
\text { Intern }\end{array}$ & \multirow[t]{3}{*}{ a. Minat } & \multirow{2}{*}{$\begin{array}{l}\text { Ketertarikan } \\
\text { pada } \\
\text { pembelajaran } \\
\text { aljabar }\end{array}$} & \multirow{2}{*}{66} & \multirow{2}{*}{ Lemah } \\
\hline \multirow[t]{7}{*}{ 1.1. Siswa } & & & & \\
\hline & & $\begin{array}{l}\text { Sikap terhadap } \\
\text { pembelajaran } \\
\text { aljabar }\end{array}$ & 60 & Cukup \\
\hline & \multirow[t]{2}{*}{ b. Motivasi } & $\begin{array}{l}\text { Perhatian } \\
\text { terhadap } \\
\text { pembelajaran } \\
\text { aljabar }\end{array}$ & 58 & Cukup \\
\hline & & $\begin{array}{l}\text { Usaha untuk } \\
\text { belajar aljabar }\end{array}$ & 77 & Lemah \\
\hline & \multirow[t]{2}{*}{ c. Bakat } & $\begin{array}{l}\text { Pemahaman } \\
\text { terhadap } \\
\text { aljabar }\end{array}$ & 67 & Lemah \\
\hline & & $\begin{array}{l}\text { Kemampuan } \\
\text { dalam } \\
\text { menyelesaikan } \\
\text { soal aljabar }\end{array}$ & 64 & Lemah \\
\hline & $\begin{array}{l}\mathrm{d} . \\
\text { Intelegensi }\end{array}$ & $\begin{array}{l}\text { Kecakapan } \\
\text { dalam } \\
\text { menyelesaikan } \\
\text { persoalan } \\
\text { aljabar }\end{array}$ & 66 & Lemah \\
\hline $\begin{array}{l}\text { Faktor } \\
\text { Ekstern }\end{array}$ & $\begin{array}{l}\text { a.Sarana/ } \\
\text { Prasarana }\end{array}$ & Ruang belajar & 73 & Lemah \\
\hline
\end{tabular}

\begin{tabular}{|l|l|l|c|c|}
\cline { 5 - 5 } \multicolumn{1}{|l|}{$\begin{array}{l}\text { 2.1. } \\
\text { Keluarga }\end{array}$} & & $\begin{array}{l}\text { Alat-alat dan } \\
\text { buku pelajaran }\end{array}$ & 66 & Lemah \\
\hline 2.2. Guru & a. Kualitas & $\begin{array}{l}\text { Penguasaan } \\
\text { materi }\end{array}$ & 70 & Lemah \\
\cline { 5 - 5 } & & $\begin{array}{l}\text { Kejelasan } \\
\text { menerangkan }\end{array}$ & 80 & Lemah \\
\cline { 3 - 5 } & b. Metode & $\begin{array}{l}\text { Penggunaan } \\
\text { metode } \\
\text { mengajar }\end{array}$ & 72 & Lemah \\
\cline { 5 - 5 } & $\begin{array}{l}\text { Penggunaan } \\
\text { alat peraga }\end{array}$ & 46 & Cukup \\
\hline $\begin{array}{l}\text { 2.3. } \\
\text { Sekolah }\end{array}$ & a. Alat & $\begin{array}{l}\text { Fasilitas yang } \\
\text { ada }\end{array}$ & 74 & Lemah \\
\cline { 3 - 5 } & b. Gedung & Letak gedung & 75 & Lemah \\
\cline { 3 - 5 } & $\begin{array}{l}\text { Kondisi } \\
\text { gedung }\end{array}$ & 57 & Cukup \\
\hline
\end{tabular}

TABEL 5

KUALIFIKASI FAKTOR-FAKTOR PENYEBAB KESULITAN BELAJAR SISWA

\begin{tabular}{|c|c|}
\hline Persentase Penyebab (\%) & Kriteria \\
\hline $81-100$ & Sangat Lemah \\
\hline $61-80$ & Lemah \\
\hline $41-60$ & Cukup \\
\hline $21-40$ & Kuat \\
\hline $0-20$ & Sangat Kuat \\
\hline
\end{tabular}

Sumber: (Riduwan, 2002: 15)

Hasil di atas menunjukkan bahwa faktor intern dengan indikator sikap siswa terhadap pembelajaran aljabar dan indikator perhatian siswa terhadap pembelajaran aljabar berada dalam kualifikasi cukup, hal ini berarti sikap dan perhatian siswa dalam pembelajaran aljabar belum cukup optimal. Sedangkan dari faktor ekstern dengan indikator penggunaaan alat peraga oleh guru dan indikator kondisi gedung berada dalam kualifikasi cukup, ini berarti penggunaan alat peraga dari guru belum cukup optimal dan kondisi gedung di sekolah cukup mempengaruhi. Sedangkan untuk indikator yang lainnya telah masuk dalam kualifikasi lemah, sehingga dapat dikatakan bahwa hampir semua faktor intern dan ekstern telah terpenuhi dengan baik sehingga tidak mempengaruhi kesulitan belajar siswa dalam mempelajari aljabar.

\section{SIMPULAN DAN SARAN}

Berdasarkan hasil tes aljabar, wawancara, dan angket yang diberikan kepada siswa dapat disimpulkan antara lain: (1)Kesulitan-kesulitan yang dialami oleh siswa kelas VII SMP Negeri 3 Salatiga dalam menyelesaikan persoalan aljabar yang berkaitan dengan konsep dan prinsip. Pada penguasaan konsep, siswa masih mengalami kesulitan dalam menentukan suku-suku sejenis dan tidak sejenis. Indikator penguasaan konsep tersebut berada didalam kategori sedang yaitu 58\%. Pada penguasaan prinsip, siswa masih mengalami kesulitan dalam menyederhanakan hasil operasi penjumlahan dan pengurangan bentuk aljabar. Indikator penguasaan prinsip tesebut berada didalam kategori sedang yaitu 53\%. Serta siswa juga mengalami kesulitan dalam menyederhanakan hasil operasi pecahan aljabar dengan indikator sedang yaitu $44 \%$. 
Serta terdapat faktor-faktor yang menyebabkan kesulitan belajar siswa kelas VII SMP Negeri 3 Salatiga dalam mempelajari aljabar berasal dari faktor intern, yaitu motivasi siswa dalam memperhatikan pembelajaran aljabar yang cenderung rendah. Serta terdapat faktor ekstern pada penggunaan alat peraga dari guru yang mempengaruhi pembelajaran belum dapat optimal.

Pada penelitian ini peneliti memberikan saran untuk peneliti lain yang sedang melakukan penelitian sejenis dengan menggunakan materi selain aljabar dalam matematika atau untuk materi aljabar tetapi dengan sub pokok bahasan yang lain serta penelitian ini dapat menjadikan salah satu penelitian pendukung. Serta, bagi guru agar penelitian ini bermanfaat untuk mengetahui letak kesulitan siswa dalam mempelajari aljabar.

\section{UCAPAN TERIMAKASIH}

Penulis mengucapkan terimakasih kepada Prof. Dr. Sutriyono, M.Sc., Ph.D. selaku pembimbing yang senantiasa memberikan bimbingan, nasehat, dan motivasi kepada penulis sehingga penelitian ini dapat terselesaikan dengan baik. Serta penulis juga mengucapkan terimakasih kepada kedua orang tua yang senantiasa memberikan nasehat dan motivasi kepada penulis.

\section{DAFTAR RUJUKAN}

Cooney,T.J.,Davis,E.V.\&,Henderson,K.B. (1975). Dinamics of Teaching Secondary School Mathematics. Boston: Houghton Mifflin Company.

Depdikbud. (1982). Pedoman Umum Ejaan yang Disempurnakan. Jakarta : Pusat dan Pengembangan Bahasa - Depdikbud.

Depdiknas. (2006). Model Kurikulum Tingkat Satuan Pendidikan danModel Pengembangan Silabus Mata Pelajaran SMP/MTs. Jakarta :BP Cipta Jaya.

Erman Suherman,dkk. (2001). Strategi Belajar Mengajar Kontemporer. Bandung : Depdikbud.

Fajar Hediyati. (2010)."Kajian Kesulitan Belajar Siswa Kelas VII SMP Negeri 16 Yogyakrta dalam mempelajari Aljabar". Yogyakarta : FMIPA, UNY

Herman Hudojo. (2005). Pengembangan Kurikulum dan PembelajaranMatematika. Malang : UM Pres.

R.Soedjadi. (1996) . Diagnosis Kesulitan Siswa Sekolah Dasar dalamBelajar Matematika. Jurnal Jurusan Matematika FPMIPA IKIPSurabaya. HIm : 25-33.

Riduwan. (2002). Skala Pengukuran Variabel-variabel Penelitian. Bandung : Alfabeta.

Suharsimi Arikunto. (1998) . Prosedur Penelitian. Jakarta : Rineka Cipta. 